\title{
Hydrochemical characteristics and controlling factors of natural water in the border areas of the Qinghai-Tibet Plateau
}

\author{
TIAN Yuan ${ }^{1,2},{ }^{*}$ YU Chengqun ${ }^{1}$, ZHA Xinjie ${ }^{2,3}$, GAO Xing ${ }^{3}$, DAI Erfu ${ }^{1}$ \\ 1. Lhasa National Ecological Research Station, Key Laboratory of Ecosystem Network Observation and Mod- \\ elling, Institute of Geographic Sciences and Natural Resources Research, CAS, Beijing 100101, China; \\ 2. University of Chinese Academy of Sciences, Beijing 100049, China; \\ 3. State Key Laboratory of Resources and Environmental Information System, Institute of Geographic Sciences \\ and Natural Resources Research, CAS, Beijing 100101, China
}

\begin{abstract}
The special geography and human environment of the Qinghai-Tibet Plateau has created the unique hydrochemical characteristics of the region's natural water, which has been preserved in a largely natural state. However, as the intensity of anthropogenic activities in the region has continued to increase, the water environment and hydrochemical characteristics of the Qinghai-Tibet Plateau have altered. In this study, water samples from the western, southern, and northeastern border areas of the Qinghai-Tibet Plateau, where human activities are ongoing, were collected, analyzed, and measured. The regional differences and factors controlling them were also investigated. The key results were obtained as follows. (1) Differences in the physical properties and hydrochemical characteristics, and their controlling factors, occurred in the different boundary areas of the Qinghai-Tibet Plateau. These differences were mainly the consequence of the geographical environment and geological conditions. (2) The water quality was good and suitable for drinking, with most samples meeting GB (Chinese national) and WHO (World Health Organization) drinking water standards. (3) The chemical properties of water were mainly controlled by the weathering of carbonates and the dissolution of evaporative rocks, with the former the most influential. (4) The biological quality indicators of natural water in the border areas were far superior to GB and WHO drinking water standards.
\end{abstract}

Keywords: border area of the Qinghai-Tibet Plateau; natural water; hydrochemical characteristics; controlling factors

Received: 2019-01-30 Accepted: 2019-03-20

Foundation: Key R\&D and Transformation Program of Tibet, No.XZ201901NB08; Major Science and Technology Project of Tibet, No.XZ201901NA03, No.XZ201801NA02

Author: Tian Yuan (1991-), PhD, specialized in Tibet water environment and health. E-mail: tiany.13s@igsnrr.ac.cn

"Corresponding author: Yu Chengqun (1965-), Professor and Ph.D. supervisor, specialized in Tibet agriculture and regional development. E-mail: yucq@igsnrr.ac.cn 


\section{Introduction}

Water is the most active factor in the geographical environment. It interconnects and interacts with the atmosphere, biosphere, pedosphere, and lithosphere in a dynamic process of water circulation. Water quantity and quality constantly changes during this process. Moreover, the water environment surrounding habituated areas can directly or indirectly influence human life and development (Zheng et al., 2007). The Qinghai-Tibet Plateau (QT) is termed the "Headwater of Asia," as many rivers in China and Southeast Asia begin at the plateau. The area plays an important role in the protection and construction of national ecological security barriers, as freshwater has also become the most important strategic resource following energy resources (Sun et al., 2012). Because of environmental, transportation, and social historical development constraints, among others, the development level of water resources on the QT is lower than the average level in China. The QT is currently among the regions that are less affected by human activities and less polluted on earth. Its water environment still maintains a relatively complete native state (Tian et al., 2016). However, the special alpine environment makes the plateau ecological environment sensitive and extremely fragile. With the progress of society and the development of the economy, the instability of the ecological environmental system on the QT has increased along with the pressure on resources and the environment (Zhang et al., 2015).

At present, except for the uninhabited areas of the Qiangtang Plateau in the northern part of the QT, the degree of anthropogenic activities is increasing. Particularly, with the construction of the Xinjiang-Tibet Highway (on the western QT) and the Qinghai-Tibet Highway (on the northeastern QT), as well as the opening of the Zhangmu Port and the Jilong Port (on the southern QT), the QT is more frequently connected with the regions of southern Xinjiang in China, northwestern and southern China, and Nepal. Moreover, the boundary areas will gradually become an important channel for China to open to South Asia, an important pillar of the "the Belt and Road" strategy. This will further affect the environment of the plateau and its surrounding areas, changing the environment and hydrochemistry of the local natural water, which in turn will affect the production and life of local farmers and herdsmen. In recent years, research regarding the water chemistry on the QT has focused on the major rivers and lakes and their catchments, including Yarlung Zangbo (Sarin and Krishnaswami, 1984; Wang, 2016), Senge Zangbo (Li et al., 2012; Wang et al., 2012), Three River Resource areas (Deng, 1988; Wu et al., 2008; Cao, 2013; Tan et al., 2016), Qinghai Lake (Hou et al., 2009; Jin et al., 2009; Xiao et al., 2012), Yamzhog Yumco (Sun et al., 2012; Zhang et al., 2012; Sun et al., 2013; Zhe et al., 2017), Pumayum Co (Ju et al., 2010; Zhu et al., 2010), Nam Co (Gao et al., 2008; Guo et al., 2012; Wang et al., 2013), Mapam Yumco (Yao et al., 2015). Some scholars have also studied water chemistry in some areas of the QT (Zhang and Gustafsson, 1995; Guo and Wang, 2012; Tian et al., 2015), including microorganisms (Nie, 2011; Zhang et al., 2013; Zhao et al., 2017), heavy metals and trace elements (Cao et al., 2000; Grange et al., 2001; Li et al., 2006; Sheng et al., 2012; Tian et al., 2016).

However, the existing research lacks a systematic study of the hydrochemistry and the genesis of natural water in various boundary areas where human activities occur on the QT. The author collected water samples in the western, southern and northeastern boundary areas of the QT (Figure 1 and Table 1) and measured the physical properties on site during August, 


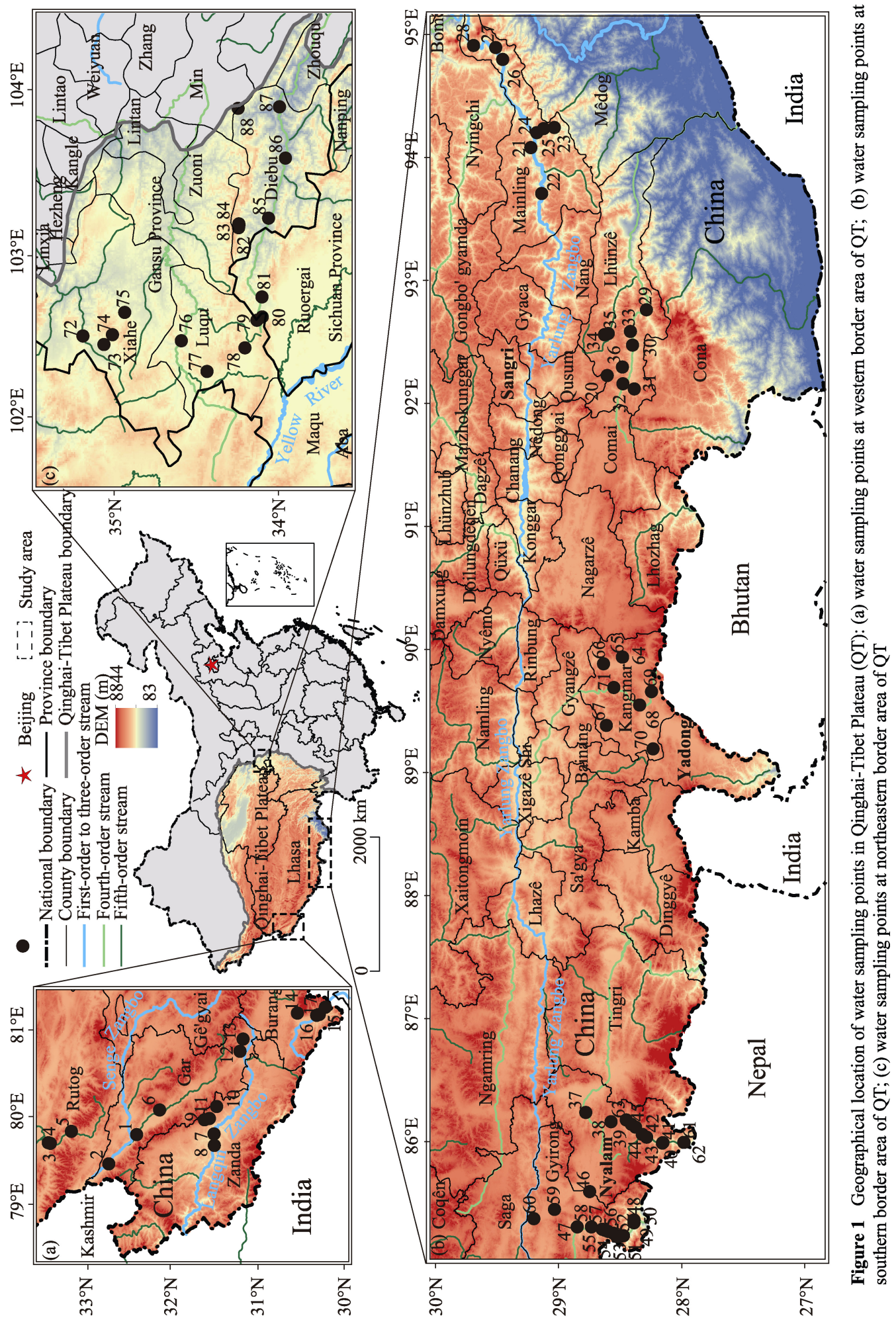


Table 1 Sampling points of water samples in the border areas of the Qinghai-Tibet Plateau

\begin{tabular}{|c|c|c|c|c|c|c|c|c|c|c|c|}
\hline No. & Type & $\begin{array}{l}\text { Town, } \\
\text { County }\end{array}$ & $\begin{array}{c}\text { Lati- } \\
\text { tude }\left(^{\circ}\right)\end{array}$ & $\begin{array}{l}\text { Longi- } \\
\text { tude }\left({ }^{\circ}\right)\end{array}$ & $\begin{array}{c}\text { Eleva- } \\
\text { tion } \\
(\mathrm{m}) \\
\end{array}$ & No. & Type & $\begin{array}{l}\text { Town, } \\
\text { County }\end{array}$ & $\begin{array}{l}\text { Lati- } \\
\text { tude }\left(^{\circ}\right)\end{array}$ & $\begin{array}{l}\text { Longi- } \\
\text { tude }\left(^{\circ}\right)\end{array}$ & $\begin{array}{c}\text { Eleva- } \\
\text { tion } \\
(\mathrm{m})\end{array}$ \\
\hline 1 & Well (14 m) & $\begin{array}{l}\text { Zhaxigang, } \\
\text { Gaer }\end{array}$ & 32.3722 & 79.7976 & 4262 & 45 & Stream & $\begin{array}{l}\text { Yalai, } \\
\text { Nyalam }\end{array}$ & 28.4159 & 86.1307 & 4426 \\
\hline 2 & Stream & $\begin{array}{l}\text { Zhaxigang, } \\
\text { Gaer }\end{array}$ & 32.6942 & 79.4597 & 4271 & 46 & Stream & $\begin{array}{l}\text { Borong, } \\
\text { Nyalam }\end{array}$ & 28.7547 & 85.5842 & 4643 \\
\hline 3 & Well (14 m) & $\begin{array}{l}\text { Rituzong, } \\
\text { Ritu }\end{array}$ & 33.3922 & 79.7046 & 4264 & 47 & Stream & $\begin{array}{l}\text { Gyirong, } \\
\text { Gyirong }\end{array}$ & 28.3950 & 85.3294 & 2815 \\
\hline 4 & Well (15 m) & $\begin{array}{l}\text { Risong, } \\
\text { Ritu }\end{array}$ & 33.3682 & 79.6971 & 4281 & 48 & Stream & $\begin{array}{l}\text { Gyirong, } \\
\text { Gyirong }\end{array}$ & 28.3952 & 85.3525 & 2731 \\
\hline 5 & Stream & $\begin{array}{l}\text { Risong, } \\
\text { Ritu }\end{array}$ & 33.1262 & 79.8355 & 4359 & 49 & Stream & $\begin{array}{l}\text { Gyirong, } \\
\text { Gyirong }\end{array}$ & 28.4812 & 85.2251 & 3171 \\
\hline 6 & Stream & $\begin{array}{l}\text { Kunsha, } \\
\text { Gaer }\end{array}$ & 32.1069 & 80.0823 & 4293 & 50 & Stream & $\begin{array}{l}\text { Gyirong, } \\
\text { Gyirong }\end{array}$ & 28.5006 & 85.2215 & 3261 \\
\hline 7 & Well (10 m) & $\begin{array}{l}\text { Tuolin, } \\
\text { Zhada }\end{array}$ & 31.4778 & 79.8051 & 3712 & 51 & Stream & $\begin{array}{l}\text { Gyirong, } \\
\text { Gyirong }\end{array}$ & 28.5346 & 85.2195 & 3409 \\
\hline 8 & Well (8 m) & $\begin{array}{l}\text { Tuolin, } \\
\text { Zhada }\end{array}$ & 31.4757 & 79.6732 & 3621 & 52 & Stream & $\begin{array}{l}\text { Gyirong, } \\
\text { Gyirong }\end{array}$ & 28.5418 & 85.2285 & 3510 \\
\hline 9 & Stream & $\begin{array}{l}\text { Daba, } \\
\text { Zhada }\end{array}$ & 31.5879 & 79.9703 & 4582 & 53 & Stream & $\begin{array}{l}\text { Zongga, } \\
\text { Gyirong }\end{array}$ & 28.5635 & 85.2462 & 3632 \\
\hline 10 & Stream & $\begin{array}{l}\text { Daba, } \\
\text { Zhada }\end{array}$ & 31.5314 & 79.9843 & 4493 & 54 & Stream & $\begin{array}{l}\text { Zongga, } \\
\text { Gyirong }\end{array}$ & 28.6056 & 85.2599 & 3760 \\
\hline 11 & Stream & $\begin{array}{l}\text { Daba, } \\
\text { Zhada }\end{array}$ & 31.4484 & 80.1229 & 4693 & 55 & Stream & $\begin{array}{l}\text { Zongga, } \\
\text { Gyirong }\end{array}$ & 28.6301 & 85.2691 & 3736 \\
\hline 12 & Stream & $\begin{array}{l}\text { Menshi, } \\
\text { Gaer }\end{array}$ & 31.1789 & 80.7601 & 4450 & 56 & Stream & $\begin{array}{l}\text { Zongga, } \\
\text { Gyirong }\end{array}$ & 28.6533 & 85.2781 & 3785 \\
\hline 13 & Stream & $\begin{array}{l}\text { Menshi, } \\
\text { Gaer }\end{array}$ & 31.1426 & 80.9014 & 4636 & 57 & Stream & $\begin{array}{l}\text { Zongga, } \\
\text { Gyirong }\end{array}$ & 28.7397 & 85.2965 & 3955 \\
\hline 14 & Well (10 m) & $\begin{array}{l}\text { Pulan, } \\
\text { Pulan }\end{array}$ & 30.2945 & 81.1759 & 3905 & 58 & Stream & $\begin{array}{l}\text { Zongga, } \\
\text { Gyirong }\end{array}$ & 28.8557 & 85.2968 & 4145 \\
\hline 15 & Well (5 m) & $\begin{array}{l}\text { Kejia, } \\
\text { Pulan }\end{array}$ & 30.1927 & 81.2707 & 3734 & 59 & Stream & $\begin{array}{l}\text { Zheba, } \\
\text { Gyirong }\end{array}$ & 29.0409 & 85.4394 & 4733 \\
\hline 16 & Stream & $\begin{array}{l}\text { Kejia, } \\
\text { Pulan }\end{array}$ & 30.2633 & 81.1870 & 3891 & 60 & Stream & $\begin{array}{l}\text { Zheba, } \\
\text { Gyirong }\end{array}$ & 29.2074 & 85.3636 & 4527 \\
\hline 17 & Stream & $\begin{array}{l}\text { Namu- } \\
\text { mani, } \\
\text { Pulan }\end{array}$ & 30.5157 & 81.2018 & 4521 & 61 & Stream & $\begin{array}{l}\text { Zhangmu, } \\
\text { Nyalam }\end{array}$ & 27.9887 & 85.9828 & 2277 \\
\hline 18 & Stream & $\begin{array}{l}\text { Huoer, } \\
\text { Pulan }\end{array}$ & 30.6872 & 81.8323 & 4752 & 62 & Stream & $\begin{array}{l}\text { Zhangmu, } \\
\text { Nyalam }\end{array}$ & 27.9903 & 85.9829 & 2263 \\
\hline 19 & Stream & $\begin{array}{l}\text { Longzi, } \\
\text { Longzi }\end{array}$ & 28.4081 & 92.4628 & 3881 & 63 & Stream & $\begin{array}{l}\text { Yalai, } \\
\text { Nyalam }\end{array}$ & 28.3828 & 86.1070 & 4373 \\
\hline 20 & Stream & $\begin{array}{l}\text { Ridang, } \\
\text { Longzi }\end{array}$ & 28.6125 & 92.2153 & 4998 & 64 & Stream & $\begin{array}{l}\text { Nierudui, } \\
\text { Kangma }\end{array}$ & 28.4865 & 89.9269 & 4569 \\
\hline 21 & Stream & $\begin{array}{l}\text { Zhaxirao- } \\
\text { deng, }\end{array}$ & 29.2319 & 94.0680 & 2993 & 65 & Stream & $\begin{array}{l}\text { Nierudui, } \\
\text { Kangma }\end{array}$ & 28.4894 & 89.9265 & 4584 \\
\hline 22 & Stream & $\begin{array}{l}\text { Wiblong, } \\
\text { Milin }\end{array}$ & 29.1447 & 93.6939 & 3032 & 66 & Stream & $\begin{array}{l}\text { Nierumai, } \\
\text { Kangma }\end{array}$ & 28.6419 & 89.8728 & 4389 \\
\hline 23 & Stream & $\begin{array}{l}\text { Nanyi, } \\
\text { Milin }\end{array}$ & 29.1849 & 94.1883 & 2938 & 67 & Stream & $\begin{array}{l}\text { Zhangx- } \\
\text { iong, } \\
\text { Kangma }\end{array}$ & 28.6183 & 89.3708 & 4489 \\
\hline 24 & Stream & $\begin{array}{l}\text { Nanyi, } \\
\text { Milin }\end{array}$ & 29.1279 & 94.2226 & 3009 & 68 & Stream & $\begin{array}{l}\text { Samada, } \\
\text { Kangma }\end{array}$ & 28.3495 & 89.5377 & 4447 \\
\hline 25 & Stream & $\begin{array}{l}\text { Nanyi, } \\
\text { Milin }\end{array}$ & 29.0417 & 94.2321 & 3147 & 69 & Stream & $\begin{array}{l}\text { Samada, } \\
\text { Kangma }\end{array}$ & 28.2517 & 89.6455 & 4573 \\
\hline
\end{tabular}


(Continued)

\begin{tabular}{|c|c|c|c|c|c|c|c|c|c|c|c|}
\hline No. & Type & $\begin{array}{l}\text { Town, } \\
\text { County }\end{array}$ & $\begin{array}{c}\text { Lati- } \\
\text { tude }\left(^{\circ}\right)\end{array}$ & $\begin{array}{l}\text { Longi- } \\
\text { tude }\left({ }^{\circ}\right)\end{array}$ & $\begin{array}{c}\text { Eleva- } \\
\text { tion } \\
(\mathrm{m})\end{array}$ & No. & Type & $\begin{array}{l}\text { Town, } \\
\text { County }\end{array}$ & $\begin{array}{l}\text { Lati- } \\
\text { tude }\left(^{\circ}\right)\end{array}$ & $\begin{array}{l}\text { Longi- } \\
\text { tude }\left(^{\circ}\right)\end{array}$ & $\begin{array}{c}\text { Eleva- } \\
\text { tion } \\
(\mathrm{m})\end{array}$ \\
\hline 26 & Stream & $\begin{array}{l}\text { Danniang, } \\
\text { Milin }\end{array}$ & 29.4613 & 94.7849 & 2945 & 70 & Stream & $\begin{array}{l}\text { Gala, } \\
\text { Kangma }\end{array}$ & 28.2388 & 89.1817 & 4474 \\
\hline 27 & Stream & Pai, Milin & 29.5174 & 94.8811 & 2931 & 71 & Stream & $\begin{array}{l}\text { Kangma, } \\
\text { Kangma }\end{array}$ & 28.5587 & 89.6807 & 4298 \\
\hline 28 & Stream & Pai, Milin & 29.6977 & 94.8978 & 2821 & 72 & Stream & $\begin{array}{l}\text { Labuleng, } \\
\text { Xiahe }\end{array}$ & 35.1936 & 102.5151 & 2942 \\
\hline 29 & Stream & $\begin{array}{l}\text { Jiayu, } \\
\text { Longzi }\end{array}$ & 28.2941 & 92.7492 & 3380 & 73 & Stream & $\begin{array}{l}\text { Sangke, } \\
\text { Xiahe }\end{array}$ & 35.0651 & 102.4624 & 3207 \\
\hline 30 & Stream & $\begin{array}{l}\text { Liemai, } \\
\text { Longzi }\end{array}$ & 28.4247 & 92.5742 & 3851 & 74 & Stream & $\begin{array}{l}\text { Sangke, } \\
\text { Xiahe }\end{array}$ & 35.0126 & 102.5232 & 3399 \\
\hline 31 & Stream & $\begin{array}{l}\text { Ridang, } \\
\text { Longzi }\end{array}$ & 28.3930 & 92.1056 & 4253 & 75 & Stream & $\begin{array}{l}\text { Sangke, } \\
\text { Xiahe }\end{array}$ & 34.9377 & 102.6594 & 3249 \\
\hline 32 & Stream & $\begin{array}{l}\text { Ridang, } \\
\text { Longzi }\end{array}$ & 28.4883 & 92.2845 & 4119 & 76 & Stream & $\begin{array}{l}\text { Maai, } \\
\text { Luqu }\end{array}$ & 34.5901 & 102.4854 & 3112 \\
\hline 33 & Stream & $\begin{array}{l}\text { Xuesha, } \\
\text { Longzi }\end{array}$ & 28.6346 & 92.5459 & 4245 & 77 & Stream & $\begin{array}{l}\text { Gahai, } \\
\text { Luqu }\end{array}$ & 34.4331 & 102.2976 & 3432 \\
\hline 34 & Stream & $\begin{array}{l}\text { Xuesha, } \\
\text { Longzi }\end{array}$ & 28.6337 & 92.5489 & 4175 & 78 & Stream & $\begin{array}{l}\text { Gahai, } \\
\text { Luqu }\end{array}$ & 34.2006 & 102.4419 & 3491 \\
\hline 35 & Stream & $\begin{array}{l}\text { Xuesha, } \\
\text { Longzi }\end{array}$ & 28.6038 & 92.5566 & 3905 & 79 & Stream & $\begin{array}{l}\text { Benzilan, } \\
\text { Luqu }\end{array}$ & 34.1269 & 102.6116 & 3358 \\
\hline 36 & Stream & $\begin{array}{l}\text { Rerong, } \\
\text { Longzi }\end{array}$ & 28.4856 & 92.1489 & 4064 & 80 & Stream & $\begin{array}{l}\text { Langmu, } \\
\text { Luqu }\end{array}$ & 34.0949 & 102.6318 & 3393 \\
\hline 37 & Well (8 m) & $\begin{array}{l}\text { Menbu, } \\
\text { Nyalam }\end{array}$ & 28.7857 & 86.2255 & 4452 & 81 & Stream & $\begin{array}{l}\text { Hongxing, } \\
\text { Nuoergai }\end{array}$ & 34.0959 & 102.7545 & 3161 \\
\hline 38 & Stream & $\begin{array}{l}\text { Menbu, } \\
\text { Nyalam }\end{array}$ & 28.5812 & 86.1501 & 4857 & 82 & Stream & $\begin{array}{l}\text { Zhagana, } \\
\text { Diebu }\end{array}$ & 34.2394 & 103.1792 & 2974 \\
\hline 39 & Stream & $\begin{array}{l}\text { Yalai, } \\
\text { Nyalam }\end{array}$ & 28.4565 & 86.1650 & 4560 & 83 & Stream & $\begin{array}{l}\text { Zhagana, } \\
\text { Diebu }\end{array}$ & 34.2374 & 103.2025 & 2978 \\
\hline 40 & Stream & $\begin{array}{l}\text { Nyalam, } \\
\text { Nyalam }\end{array}$ & 28.1598 & 85.9805 & 3771 & 84 & Stream & $\begin{array}{l}\text { Zhagana, } \\
\text { Diebu }\end{array}$ & 34.2370 & 103.1979 & 2939 \\
\hline 41 & Stream & $\begin{array}{l}\text { Nyalam, } \\
\text { Nyalam }\end{array}$ & 28.1634 & 85.9768 & 3788 & 85 & Stream & $\begin{array}{l}\text { Dianga, } \\
\text { Diebu }\end{array}$ & 34.0558 & 103.2373 & 2355 \\
\hline 42 & Stream & $\begin{array}{l}\text { Yalai, } \\
\text { Nyalam }\end{array}$ & 28.2928 & 86.0248 & 4104 & 86 & Stream & $\begin{array}{l}\text { Wangzang, } \\
\text { Diebu }\end{array}$ & 33.9520 & 103.6059 & 2007 \\
\hline 43 & Stream & $\begin{array}{l}\text { Yalai, } \\
\text { Nyalam }\end{array}$ & 28.3273 & 86.0474 & 4259 & 87 & Stream & $\begin{array}{l}\text { Huayuan, } \\
\text { Diebu }\end{array}$ & 33.9885 & 103.9207 & 1733 \\
\hline 44 & Stream & $\begin{array}{l}\text { Yalai, } \\
\text { Nyalam }\end{array}$ & 28.3828 & 86.1070 & 4373 & 88 & Stream & $\begin{array}{l}\text { Sigou, } \\
\text { Minxian }\end{array}$ & 34.2426 & 103.9113 & 2948 \\
\hline
\end{tabular}

October and November 2017. During September and December of 2017, the author analyzed and tested the elemental contents of the water at the Physical and Chemical Analysis Center of the Institute of Geographic Sciences and Natural Resources Research, Chinese Academy of Sciences (IGSNRR, CAS). Based on the collection and analysis of water samples from the three boundary areas of the QT, the hydrochemistry and causes of natural waters in different boundary areas of the QT were studied, and a comparison of regional differences between different boundary areas was completed. 


\section{Materials and methods}

\subsection{Study area}

The QT has a land area of $2.57 \times 10^{6} \mathrm{~km}^{2}\left(26.0033^{\circ}-39.7806^{\circ} \mathrm{N}, 73.3144^{\circ}-104.7831^{\circ} \mathrm{E}\right)$ along the southwestern border of China, with an average elevation higher than $4000 \mathrm{~m}$ above sea level (Zhang et al., 2002). The northeastern border areas of the QT are in the transitional zone between the QT and the Loess Plateau. The terrain is higher in elevation to the northwest (meadow steppe) and lower to the southeast (the Min-Die mountain area). The southern border areas are in the Himalayas and the geomorphological type is mainly deep-cutting alpine gorge and plateau strath lake basin. The western border areas are on the western Qiangtang Plateau, where the Kunlun Mountains, Gangdese Mountains, and Himalayas are distributed to the north, central, and south, respectively. Here, the geomorphological type is mainly plateau lake basin, river valley, terrestrial forest, and alpine gully. Since the Proterozoic, the strata of the system have been well developed, and the sedimentary rock types are diverse atop the QT, particularly the well-exposed Mesozoic-Cenozoic marine strata. Igneous rocks and metamorphic rocks are widely distributed, various rock types are exposed, and the rock types are complex (Lu et al., 2016). Rainfall and runoff are abundant to the east and south, and the supply of surface water and groundwater is sufficient; however, the climate to the west and north is arid, comprising a global cold and arid core. The average annual precipitation of each boundary sampling county is approximately $620 \mathrm{~mm}$ (northeastern boundary), $570 \mathrm{~mm}$ (southern boundary), and $130 \mathrm{~mm}$ (western boundary), respectively (NBS, 2017). In 2016, the county gross domestic product (GDP) of prefecture-level cities in the border areas of the QT was 1.707 billion yuan (along the northeastern border; Gannan Tibetan Autonomous Prefecture), 1.12 billion yuan (along the southern border; Shigatse City, Shannan City, and Nyingchi City), and 604 million yuan (along the eastern border, Ali (Ngari) Prefecture), respectively (NBS, 2017).

\subsection{Field measurement}

The location at each collection sample recorded the coordinate by using a handheld GPS (Global Position System) device (equipment model: 530HCx, produced by GARMIN). The $\mathrm{pH}$, Ec (electrical conductivity) and $\mathrm{T}$ (temperature) were in-situ tested by using a $\mathrm{pH}$ tester (Limit of detection (LOD): 0.01, equipment model: SX-620, produced by Sanxing, Shanghai) and Ec tester (LOD: $0.1 \mu \mathrm{S} / \mathrm{cm}$, equipment model: SX-650, produced by Sanxing, Shanghai) respectively. The TDS (total dissolved solids) were automatically converted by the instrument through Ec. Collection and preservation of all water samples are followed the Standard Examination Methods for Drinking Water (GB/T 5750-2006) (MH, 2007).

\subsection{Laboratory analysis method}

The bicarbonate $\left(\mathrm{CO}_{3}^{2-}\right)$ and carbonate $\left(\mathrm{HCO}_{3}^{-}\right)$were analyzed using an acid-base titration according to the method of Ministry of Health (MH) of the P.R.C. (MEP, 2002; MH, 2007). Anions of chlorine $\left(\mathrm{Cl}^{-}\right)$, sulfate $\left(\mathrm{SO}_{4}^{2-}\right)$, nitrate $\left(\mathrm{NO}_{3}^{-}\right)$, fluorine $\left(\mathrm{F}^{-}\right)$, phosphate $\left(\mathrm{PO}_{4}^{3-}\right)$ and nitrite $\left(\mathrm{NO}_{2}^{-}\right)$were analyzed using IC (Ion Chromatography, LOD: $0.001 \mathrm{mg} / \mathrm{L}$, equipment model: ICS-900, produced by Thermo Fisher Scientific) at the IGSNRR, following the U.S. Environmental Protection Agency (EPA) method 300.0 (EPA, 1993). Major cations of calcium $\left(\mathrm{Ca}^{2+}\right)$, potassium $\left(\mathrm{K}^{+}\right)$, magnesium $\left(\mathrm{Mg}^{2+}\right)$, sodium $\left(\mathrm{Na}^{+}\right)$and silicon $(\mathrm{Si})$ were deter- 
mined using ICP-OES (Inductively Coupled Plasma Optical Emission Spectrometry, LOD: $0.001 \mathrm{mg} / \mathrm{L}$, equipment model: Optima $5300 \mathrm{DV}$, produced by PerkinElmer). Quality assurance were controlled by using certified external standard solutions and retested sample measurements (retest 1 sample after run every 10 samples) during the analysis to ensure and verify the stability of the results. Certified external standard of cations solutions for $\mathrm{Ca}^{2+}, \mathrm{K}^{+}$, $\mathrm{Mg}^{2+}, \mathrm{Na}^{+}$, and $\mathrm{Si}$ were prepared from Multi-element ICP-MS calibration standards (No.Lot\# 15-76JB and Cat\# N9300233). Certified external standard of anions solutions were prepared from $\mathrm{GB}$ of $\mathrm{F}^{-}$(GBW080549), $\mathrm{Cl}^{-}$ (GBW080268), $\quad \mathrm{SO}_{4}^{2-} \quad$ (GBW080266), $\mathrm{PO}_{4}^{3-}$ (GBW080435), $\mathrm{NO}_{3}^{-}$(GBW080264) and $\mathrm{NO}_{2}^{-}$ (GBW080223), respectively.

The relative error of total anion and cation (equivalent ratio) in 88 samples ranged from $0.01 \%$ to $4.67 \%$, less than $5.00 \%$ (Figure 2). Therefore, it can be said that the total anion and cation in the measured water are basically balanced (Shen et al., 1993), i.e., our data are accurate and reliable.

\section{Results and discussion}

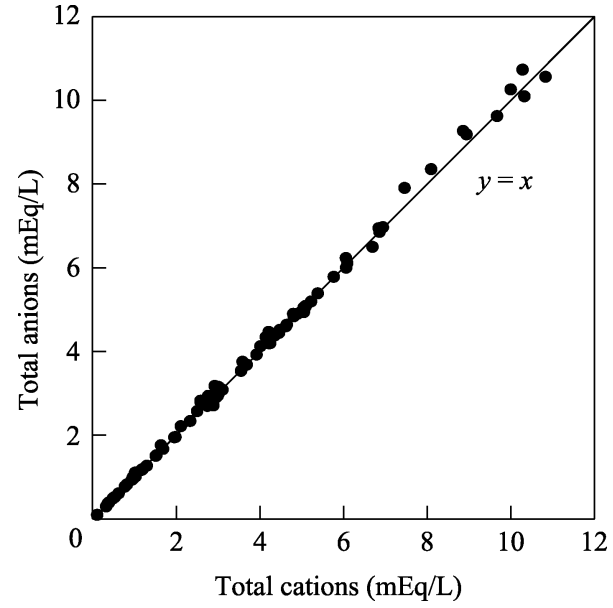

Figure 2 Total cation $(\mathrm{mEq} / \mathrm{L})$ and total anion $(\mathrm{mEq} / \mathrm{L})$ relative error of water samples on the Qinghai-Tibet Plateau

\subsection{Elements concentrations}

The water samples of QT border areas have suitable hydrochemical characteristics (Table 2). The $\mathrm{pH}$ value ranged from 6.52 to 8.88 (mean value: 7.75), and the TDS ranged from 6.11 $\mathrm{mg} / \mathrm{L}$ to $583 \mathrm{mg} / \mathrm{L}$ (mean value: $180 \mathrm{mg} / \mathrm{L}$ ). The TH (hardness) of the QT border area water samples was calculated, ranging between $3.69 \mathrm{mmol} / \mathrm{L}$ and $512 \mathrm{mmol} / \mathrm{L}$ (mean value: 168 $\mathrm{mmol} / \mathrm{L})$.

Significant spatial variations in the major cations and anions indicate the impact of different lithologies and anthropogenic activities at a watershed scale (Li and Zhang, 2008). The statistical data (min, max, mean, median, SD, skewness) for the major elemental composition of the water samples in different QT border areas are listed in Table 2. The water samples major cations relative concentration order is $\mathrm{K}^{+}<\mathrm{Mg}^{2+}<\mathrm{Na}^{+}<\mathrm{Ca}^{2+}$ (in the western QT border area) and $\mathrm{K}^{+}<\mathrm{Na}^{+}<\mathrm{Mg}^{2+}<\mathrm{Ca}^{2+}$ (in the southern and northeastern QT border areas), while order of the anions in water samples is $\mathrm{NO}_{3}^{-}<\mathrm{Cl}^{-}<\mathrm{SO}_{4}^{2-}<\mathrm{HCO}_{3}^{-}$(in the western QT border area) and $\mathrm{NO}_{3}^{-}<\mathrm{Cl}^{-}<\mathrm{SO}_{4}^{2-}<\mathrm{HCO}_{3}^{-}$(in the southern and northeastern QT border areas) (Table 2). The lowest TDS and TH of the water samples on the QT was found in the western border area, with a mean value of $142.01 \mathrm{mg} / \mathrm{L}$ and $122.55 \mathrm{mg} / \mathrm{L}$ respectively.

Natural water in different QT border areas is mainly fresh-soft water and fresh-hard water. No water samples in the QT border areas with high TDS $(>1000 \mathrm{mg} / \mathrm{L})$ and TH $(>1000$ $\mathrm{mg} / \mathrm{L}$ ) were classified as brackish-hard water (Figure 3). Most water samples from western border of the QT were fresh-soft water, but water samples from the northeastern border of the QT were fresh-hard water (Figure 3). 
Table 2 Parameters and elements concentration statistical summary of the water samples of the Qinghai-Tibet Plateau border areas

\begin{tabular}{|c|c|c|c|c|c|c|c|c|c|c|c|c|c|}
\hline \multicolumn{2}{|c|}{ Parameters } & $\mathrm{pH}$ & TDS & $\mathrm{TH}$ & $\mathrm{Ca}^{2+}$ & $\mathrm{K}^{+}$ & $\mathrm{Mg}^{2+}$ & $\mathrm{Na}^{+}$ & $\mathrm{HCO}_{3}^{-}$ & $\mathrm{Cl}^{-}$ & $\mathrm{SO}_{4}^{2-}$ & $\mathrm{NO}_{3}^{-}$ & $\mathrm{Si}$ \\
\hline \multicolumn{2}{|c|}{ Unit } & & $\mathrm{mg} / \mathrm{L}$ & $\mathrm{mmol} / \mathrm{L}$ & $\mathrm{mg} / \mathrm{L}$ & $\mathrm{mg} / \mathrm{L}$ & $\mathrm{mg} / \mathrm{L}$ & $\mathrm{mg} / \mathrm{L}$ & $\mathrm{mg} / \mathrm{L}$ & $\mathrm{mg} / \mathrm{L}$ & $\mathrm{mg} / \mathrm{L}$ & $\mathrm{mg} / \mathrm{L}$ & $\mathrm{mg} / \mathrm{L}$ \\
\hline \multirow{6}{*}{ All } & Min & 6.52 & 6.11 & 3.69 & 1.10 & 0.00 & 0.19 & 0.19 & 2.95 & 0.00 & 1.29 & 0.00 & 2.08 \\
\hline & Max & 8.88 & 583 & 512 & 149 & 8.43 & 71.0 & 32.8 & 305 & 21.7 & 356 & 32.2 & 20.7 \\
\hline & Mean & 7.75 & 180 & 168 & 44.7 & 1.03 & 13.5 & 6.06 & 127 & 2.33 & 59.2 & 2.60 & 8.77 \\
\hline & Median & 7.75 & 171 & 143 & 42.3 & 0.87 & 9.02 & 3.75 & 109 & 0.68 & 28.7 & 1.15 & 7.64 \\
\hline & SD & 0.50 & 130 & 127 & 30.9 & 1.06 & 14.6 & 6.30 & 95.8 & 3.98 & 80.8 & 4.48 & 4.10 \\
\hline & Skewness & -0.04 & 1.13 & 0.88 & 0.77 & 3.89 & 1.75 & 1.66 & 0.37 & 2.94 & 2.03 & 4.33 & 0.85 \\
\hline \multirow{6}{*}{ West } & Min & 6.99 & 32.9 & 27.6 & 9.38 & 0.00 & 0.99 & 0.19 & 16.4 & 0.00 & 3.48 & 0.00 & 4.85 \\
\hline & Max & 8.88 & 391 & 394 & 69.3 & 8.43 & 52.9 & 32.8 & 302 & 21.7 & 199 & 32.2 & 20.7 \\
\hline & Mean & 8.38 & 142 & 122 & 31.0 & 1.44 & 10.6 & 10.8 & 106 & 5.62 & 46.9 & 3.41 & 10.2 \\
\hline & Median & 7.74 & 171 & 146 & 42.4 & 0.86 & 9.09 & 3.54 & 108 & 0.67 & 29.6 & 1.17 & 7.50 \\
\hline & SD & 0.44 & 79.1 & 82.8 & 17.4 & 1.77 & 11.1 & 8.37 & 70.1 & 6.79 & 45.0 & 7.42 & 4.96 \\
\hline & Skewness & -1.97 & 1.45 & 1.76 & 0.54 & 3.37 & 2.95 & 0.74 & 0.92 & 1.08 & 2.13 & 3.23 & 0.75 \\
\hline \multirow{6}{*}{ South } & Min & 6.52 & 6.11 & 3.69 & 1.10 & 0.00 & 0.19 & 0.38 & 2.95 & 0.31 & 1.29 & 0.40 & 2.08 \\
\hline & Max & 8.07 & 583 & 512 & 149 & 2.72 & 58.7 & 23.7 & 305 & 9.84 & 356 & 19.2 & 18.3 \\
\hline & Mean & 7.57 & 187 & 163 & 44.5 & 0.77 & 12.5 & 4.32 & 98.6 & 0.96 & 74.4 & 1.74 & 8.46 \\
\hline & Median & 7.66 & 131 & 128 & 38.4 & 0.64 & 5.30 & 3.02 & 74.3 & 0.57 & 38.3 & 1.04 & 6.95 \\
\hline & SD & 0.36 & 156 & 146 & 36.0 & 0.68 & 15.2 & 4.68 & 90.6 & 1.68 & 95.7 & 2.71 & 4.04 \\
\hline & Skewness & -1.11 & 0.92 & 0.90 & 0.85 & 0.76 & 1.44 & 1.92 & 0.93 & 4.47 & 1.51 & 5.30 & 0.68 \\
\hline \multirow{6}{*}{ Northeast } & Min & 6.87 & 119 & 148 & 40.6 & 0.34 & 4.44 & 0.99 & 162 & 0.97 & 3.35 & 0.92 & 3.51 \\
\hline & Max & 8.14 & 330 & 462 & 81.9 & 2.87 & 71.0 & 20.6 & 298 & 12.4 & 139 & 16.3 & 14.0 \\
\hline & Mean & 7.66 & 198 & 231 & 59.9 & 1.40 & 19.5 & 6.50 & 238 & 3.11 & 24.5 & 4.38 & 8.22 \\
\hline & Median & 7.77 & 198 & 224 & 58.1 & 1.00 & 17.1 & 4.34 & 250 & 2.54 & 15.7 & 2.09 & 8.04 \\
\hline & SD & 0.40 & 47.7 & 66.8 & 12.0 & 0.76 & 14.4 & 5.48 & 37.2 & 2.58 & 31.2 & 3.96 & 2.64 \\
\hline & Skewness & -0.68 & 0.91 & 2.27 & 0.14 & 0.47 & 2.54 & 1.55 & -0.28 & 2.70 & 2.90 & 1.59 & 0.34 \\
\hline
\end{tabular}

Note: SD means standard deviation

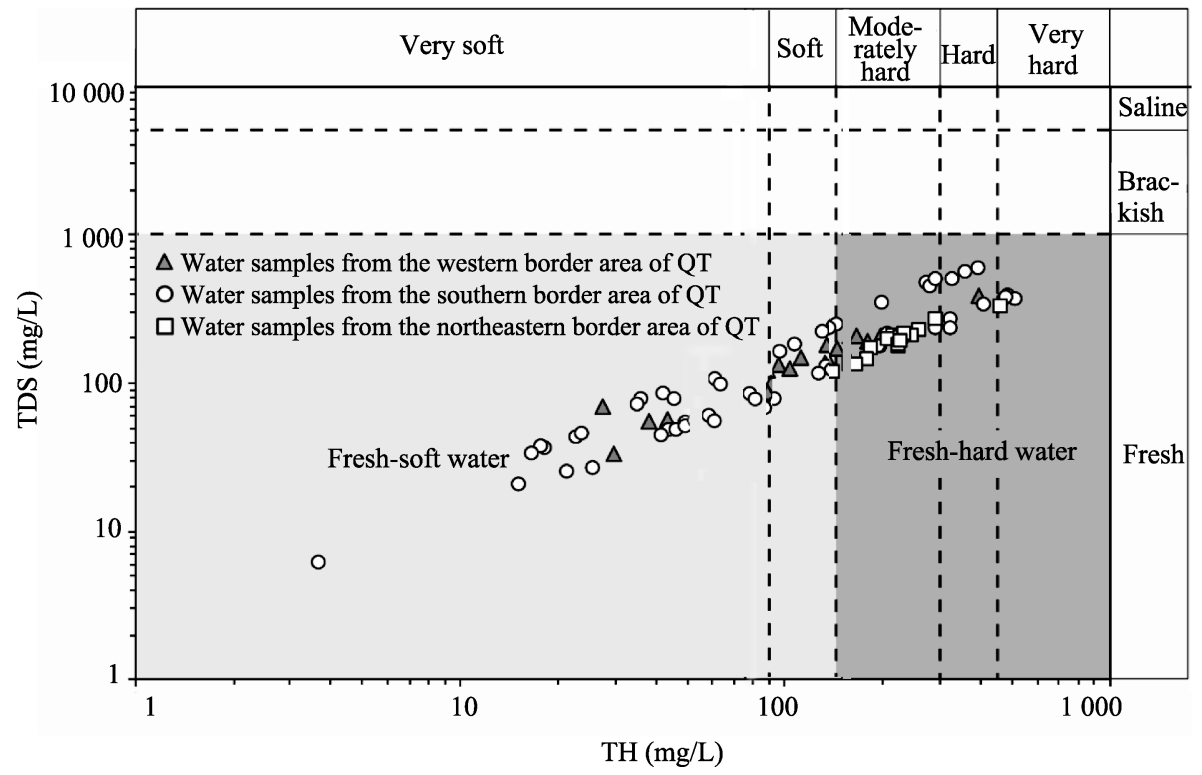

Figure 3 Water quality of water samples in different border areas of the Qinghai-Tibet Plateau 
In Table 3, TDS, $\mathrm{Ca}^{2+}, \mathrm{Mg}^{2+}, \mathrm{Na}^{+}$, and $\mathrm{Cl}^{-}$in all of the water samples of QT border areas were less than the drinking water standards of both GB and WHO. The $\mathrm{pH}$ value of all the water samples meets the WHO drink water standard and all the water samples of southern and northeastern QT border areas meet both standards. However, only 50\% of the water samples from the western border of the QT meet the GB standard (Table 3), while 7.5\% and $5.9 \%$ of the water samples in the southern and northeastern QT border areas exceed the GB TH standard, respectively. Only one water sample in the QT southern border area exceeds the WHO drinking water standard (Table 3). Approximately $11 \%$ of the water samples in the southern QT border areas exceed the $\mathrm{SO}_{4}^{2-}$ value of the two drinking water standards. The $\mathrm{NO}_{3}^{-}$value of all the water samples meets the $\mathrm{GB}$ and WHO drinking water standards. Therefore, the majority of the natural water in the border areas of the QT is suitable for drinking.

Table 3 Distribution of water samples exceeding the drinking water standards in border areas of the Qinghai-Tibet Plateau

\begin{tabular}{|c|c|c|c|c|c|}
\hline \multirow{2}{*}{ Parameters } & \multirow{2}{*}{ 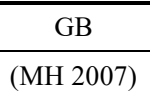 } & \multirow{2}{*}{$\frac{\text { WHO }}{\text { (WHO 2008) }}$} & \multicolumn{3}{|c|}{ Number of exceeding the drinking water standards } \\
\hline & & & West & South & Northeast \\
\hline $\mathrm{pH}$ & $6.5-8.5$ & $6.5-9.5$ & $9(50 \%)$ & 0 & 0 \\
\hline TDS & 1000 & 1000 & 0 & 0 & 0 \\
\hline $\mathrm{TH}$ & 450 & 500 & 0 & $4(7.5 \%)$ & $1(5.9 \%)$ \\
\hline $\mathrm{Ca}^{2+}$ & - & 300 & 0 & 0 & 0 \\
\hline $\mathrm{Mg}^{2+}$ & - & 300 & 0 & 0 & 0 \\
\hline $\mathrm{Na}^{+}$ & 200 & 200 & 0 & 0 & 0 \\
\hline $\mathrm{Cl}^{-}$ & 250 & 250 & 0 & 0 & 0 \\
\hline $\mathrm{SO}_{4}^{2-}$ & 250 & 250 & 0 & $6(11 \%)$ & 0 \\
\hline $\mathrm{NO}_{3}^{-}$ & 44 & 50 & 0 & 0 & 0 \\
\hline
\end{tabular}

Note: GB means Chinese State Standard

\subsection{Hydrochemical characteristics}

The relative amounts of major anions and cations in water samples of the QT border area are shown by using a Piper diagram; the hydrochemical characteristics of water was determined by the percentage of major anions and cations (Piper, 1944).

The QT border water samples are dominated by $\mathrm{Ca}^{2+}-\mathrm{Mg}^{2+}-\mathrm{HCO}_{3}^{-} \quad(\mathrm{n}=19)$, $\mathrm{Ca}^{2+}-\mathrm{Mg}^{2+}-\mathrm{HCO}_{3}^{-}-\mathrm{SO}_{4}^{2-}(\mathrm{n}=13), \mathrm{Ca}^{2+}-\mathrm{Mg}^{2+}-\mathrm{SO}_{4}^{2-}-\mathrm{HCO}_{3}^{-}(\mathrm{n}=13), \mathrm{Ca}^{2+}-\mathrm{HCO}_{3}^{-}(\mathrm{n}=13)$ and $\mathrm{Ca}^{2+}-\mathrm{HCO}_{3}^{-}-\mathrm{SO}_{4}^{2-}(\mathrm{n}=10)$, with an average $\mathrm{pH}$ of 7.75 (Table 2). In different water samples, some observations are as follows: (1) Most water samples of the western border are weakly alkaline (average $\mathrm{pH}$ is 8.38 ) (Table 2); $\mathrm{Ca}^{2+}-\mathrm{Mg}^{2+}-\mathrm{HCO}_{3}^{-}-\mathrm{SO}_{4}^{2-}(\mathrm{n}=4)$ and $\mathrm{Ca}^{2+}-\mathrm{Mg}^{2+}-\mathrm{SO}_{4}^{2-}-\mathrm{HCO}_{3}^{-}(\mathrm{n}=2)$ are the most common water types. (2) Most water samples of the southern border are slightly alkaline (average $\mathrm{pH}$ is 7.57) (Table 2); $\mathrm{Ca}^{2+}-\mathrm{Mg}^{2+}$ $\mathrm{SO}_{4}^{2-}-\mathrm{HCO}_{3}^{-}(\mathrm{n}=11), \mathrm{Ca}^{2+}-\mathrm{Mg}^{2+}-\mathrm{HCO}_{3}^{-}-\mathrm{SO}_{4}^{2-}(\mathrm{n}=9), \mathrm{Ca}^{2+}-\mathrm{HCO}_{3}^{-}-\mathrm{SO}_{4}^{2-}(\mathrm{n}=9), \mathrm{Ca}^{2+}-$ $\mathrm{Mg}^{2+}-\mathrm{HCO}_{3}^{-}(\mathrm{n}=7)$, and $\mathrm{Ca}^{2+}-\mathrm{HCO}_{3}^{-}(\mathrm{n}=7)$ are the most common water types of these water samples. (3) Most water samples of the northeastern border are slightly alkaline (average $\mathrm{pH}$ is 7.66) (Table 2); $\mathrm{Ca}^{2+}-\mathrm{Mg}^{2+}-\mathrm{HCO}_{3}^{-}(\mathrm{n}=11)$ and $\mathrm{Ca}^{2+}-\mathrm{HCO}_{3}^{-}(\mathrm{n}=4)$ are the most common water types (Figure 4). 


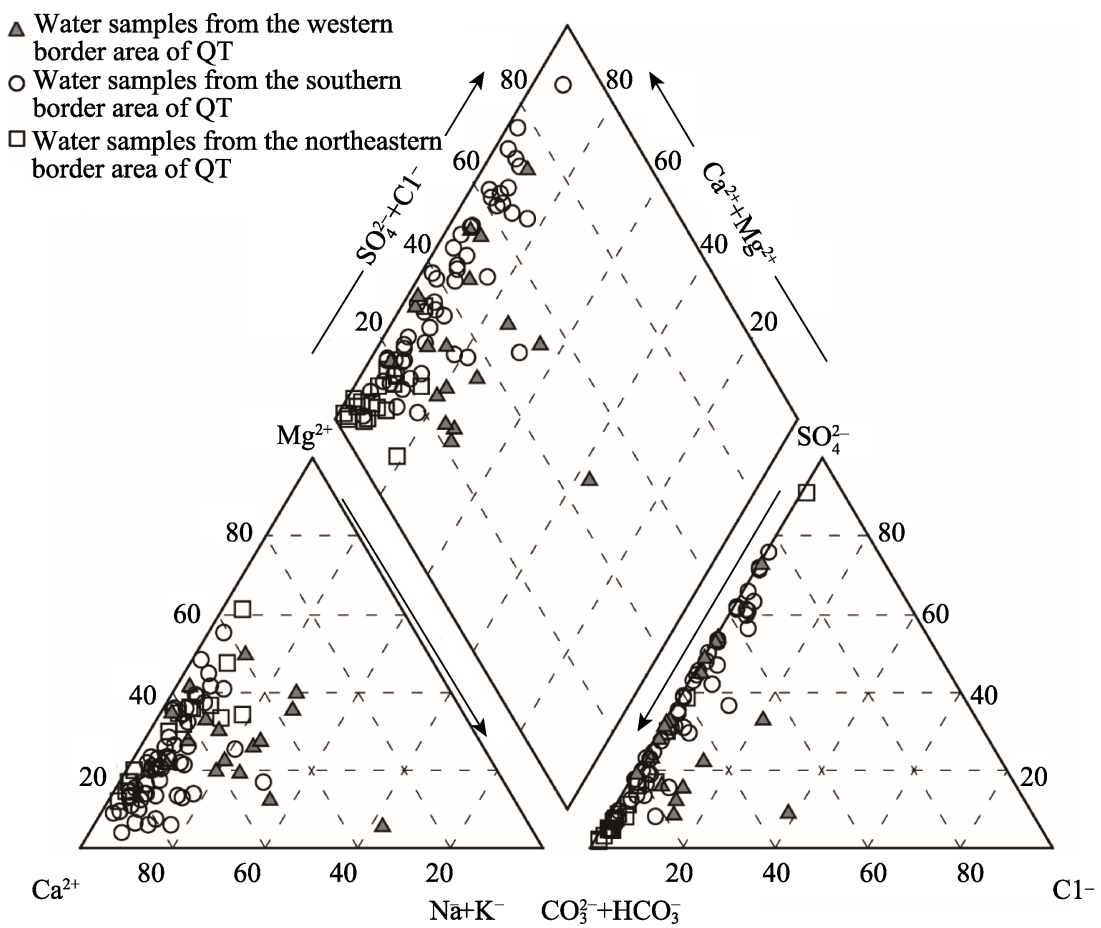

Figure 4 Piper diagrams for water samples from different border areas of the Qinghai-Tibet Plateau

\subsection{Preliminary discussion of ion sources}

Gibbs boomerang envelope (Gibbs, 1970) built a simple model by using the TDS values versus the $\mathrm{Na}^{+} /\left(\mathrm{Na}^{+}+\mathrm{Ca}^{2+}\right)$ (weight ratio) and the TDS values versus $\mathrm{Cl}^{-} /\left(\mathrm{Cl}^{-}+\mathrm{HCO}_{3}^{-}\right.$) (weight ratio) measuring the relative significance of the three types of natural factors (evaporation, weathering, and precipitation) that control surface water chemistry.

The Gibbs model plot shows that the rock weathering controls the main hydrochemical composition in the QT border areas (Figure 5), basically consistent with the previous study of rivers on the QT (Zhu et al., 2010; Yao et al., 2015; Zhe et al., 2017).

\subsection{Mechanisms controlling hydrochemistry}

A total of $11.6 \%$ of global river solutes originate from silicates, $17.2 \%$ from evaporites (although evaporites only account for approximately $1.25 \%$ of the surface rock distribution area), and approximately 50\% from carbonates (Meybeck, 1987). The major anions and cations in water which have been weathered from stratum and dissolved in water can determine the rock type, e.g., $\mathrm{Ca}^{2+}$ and $\mathrm{Mg}^{2+}$ may originate from carbonates, evaporites, or silicates; $\mathrm{Na}^{+}$and $\mathrm{K}^{+}$from both evaporites and silicates; $\mathrm{Cl}^{-}$and $\mathrm{SO}_{4}^{2-}$ mainly from the dissolution of evaporites; and $\mathrm{HCO}_{3}^{-}$mostly from weathered carbonates ( $\mathrm{Li}$ and $\mathrm{Zhang}$, 2008).

The milliequivalent $(\mathrm{mEq})$ ratio of $\mathrm{Cl}^{-}+\mathrm{SO}_{4}^{2-}$ to $\mathrm{HCO}_{3}^{-}$in the QT water samples from the western and southern border areas is approximately equal to 1 (Figure 6a). The mEq ratios of $\mathrm{Ca}^{2+}+\mathrm{Mg}^{2+}$ to $\mathrm{HCO}_{3}^{-}$(Figure 6b) and $\mathrm{Ca}^{2+}+\mathrm{Mg}^{2+}$ to $\mathrm{SO}_{4}^{2-}$ (Figure 6c) are greater than 1 . The $\mathrm{mEq}$ ratio of $\mathrm{Ca}^{2+}+\mathrm{Mg}^{2+}$ to $\mathrm{HCO}_{3}^{-}+\mathrm{SO}_{4}^{2-}$ is approximately equal to 1 (Figure $6 \mathrm{~d}$ ). This indicates that the ions in these water samples are mainly controlled by the carbonate weathering 

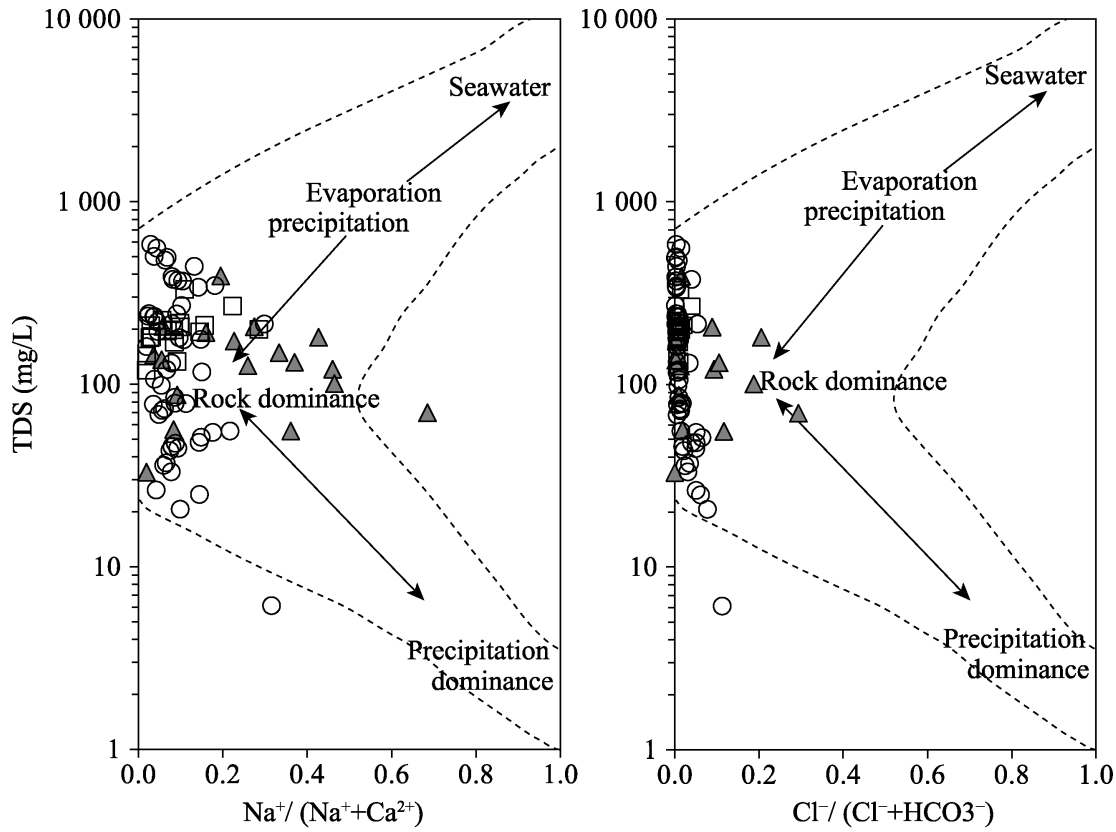

$\Delta$ Water samples from the western border area of QT

$\square$ Water samples from the northeastern border area of QT

O Water samples from the southern border area of QT

Figure 5 Gibbs boomerang envelope model plot
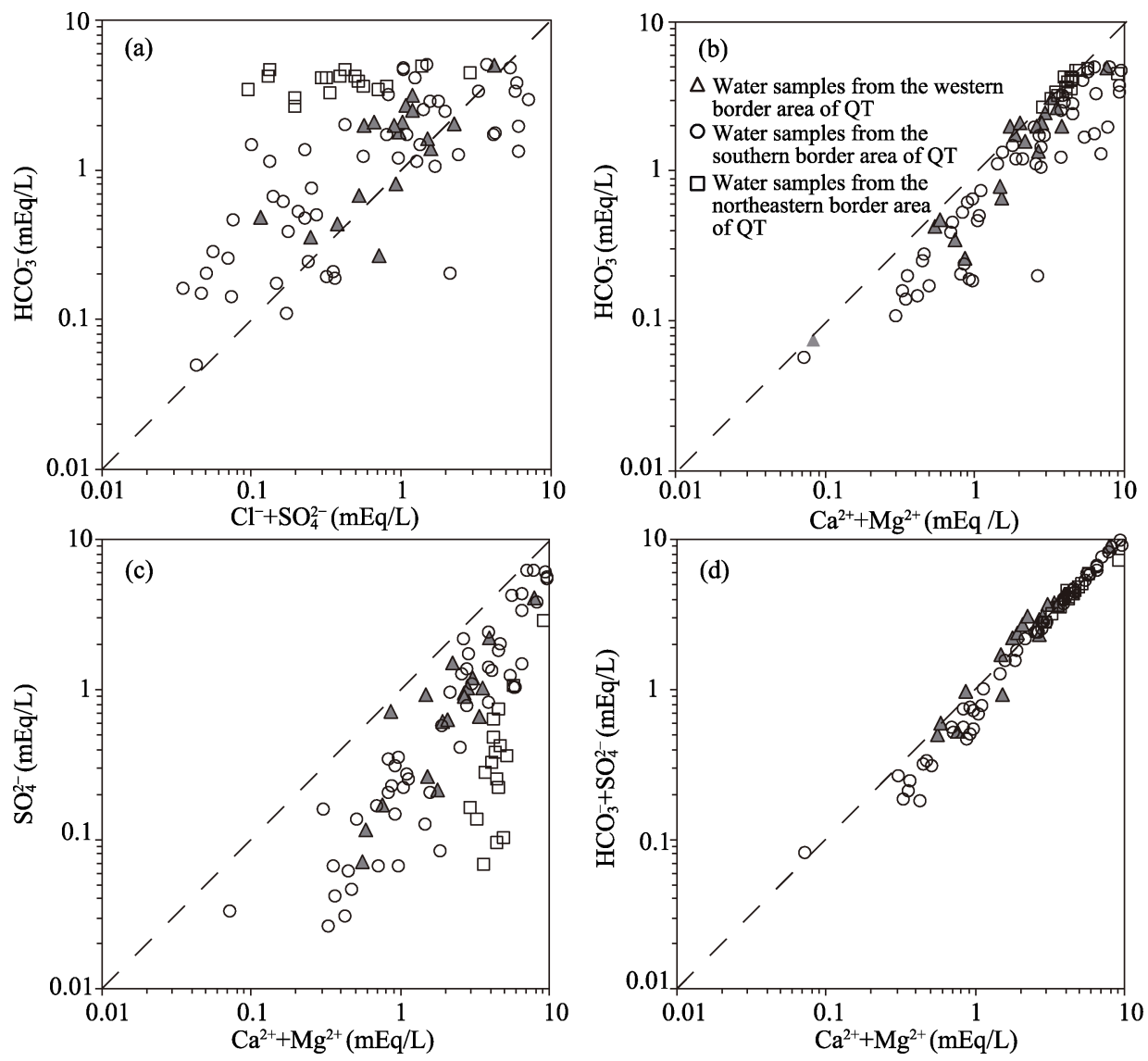

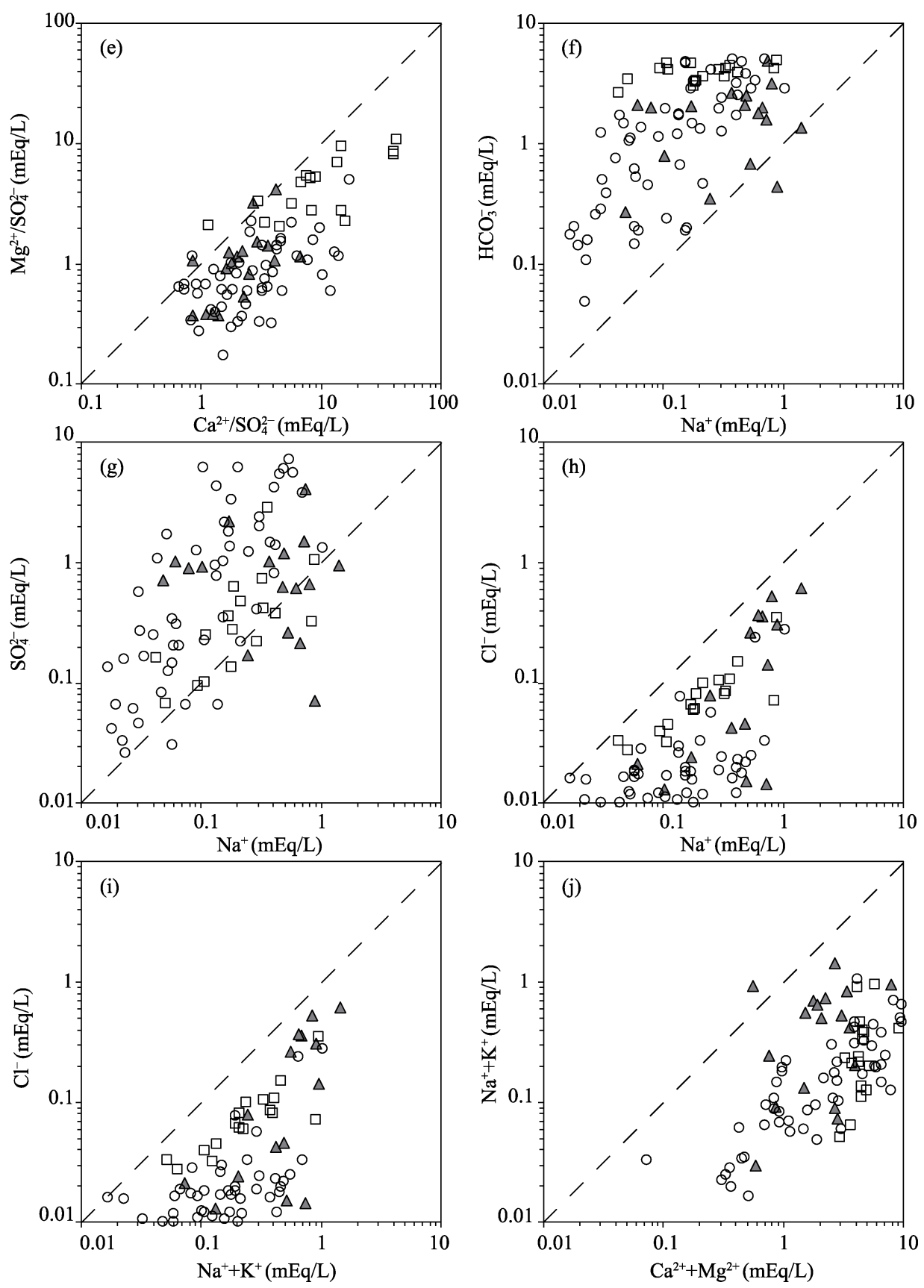

Figure 6 Scatter diagrams of (a) $\mathrm{Cl}^{-}+\mathrm{SO}_{4}^{2-}$ and $\mathrm{HCO}_{3}^{-}$, (b) $\mathrm{Ca}^{2+}+\mathrm{Mg}^{2+}$ and $\mathrm{HCO}_{3}^{-}$, (c) $\mathrm{Ca}^{2+}+\mathrm{Mg}^{2+}$ and $\mathrm{SO}_{4}^{2-}$, (d) $\mathrm{Ca}^{2+}+\mathrm{Mg}^{2+}$ and $\mathrm{HCO}_{3}^{-}+\mathrm{SO}_{4}^{2-}$, (e) $\mathrm{Ca}^{2+} / \mathrm{SO}_{4}^{2-}$ and $\mathrm{Mg}^{2+} / \mathrm{SO}_{4}^{2-}$, (f) $\mathrm{Na}^{+}$and $\mathrm{HCO}_{3}^{-}$, (g) $\mathrm{Na}^{+}$and $\mathrm{SO}_{4}^{2-}$, (h) $\mathrm{Na}^{+}$and $\mathrm{Cl}^{-}$, (i) $\mathrm{Na}^{+}+\mathrm{K}^{+}$and $\mathrm{Cl}^{-}$, (j) $\mathrm{Ca}^{2+}+\mathrm{Mg}^{2+}$ and $\mathrm{Na}^{+}+\mathrm{K}^{+}$for the water samples in different border area of the Qinghai-Tibet Plateau

and the dissolution of evaporites. This further suggests the weathering of carbonate mineral (e.g., calcite and dolomite) and dissolution of sulfate mineral (e.g., gypsum) could be crucial reactions resulting in the $\mathrm{Ca}^{2+}$ and $\mathrm{Mg}^{2+}$ in water (Dalai et al., 2002). Meanwhile, the $\mathrm{mEq}$ ratios of $\mathrm{Ca}^{2+} / \mathrm{SO}_{4}^{2-}$ to $\mathrm{Mg}^{2+} / \mathrm{SO}_{4}^{2-}$ (Figure 6e) in most of the water samples are slightly 
greater than 1 , meaning the content of $\mathrm{Ca}^{2+}$ is higher than that of $\mathrm{Mg}^{2+}$ and the sulfate dissolution contribution is less than that of carbonates weathering ( $\mathrm{Li}$ and Zhang, 2008). In the water samples from the northeastern border area of the QT, the $\mathrm{mEq}$ ratio of $\mathrm{Cl}^{-}+\mathrm{SO}_{4}^{2-}$ to $\mathrm{HCO}_{3}^{-}$(Figure 6a) is much less than 1 , the $\mathrm{mEq}$ of $\mathrm{Ca}^{2+}+\mathrm{Mg}^{2+}$ is nearly equal in proportion to $\mathrm{HCO}_{3}^{-}$(Figure 6b), and the $\mathrm{mEq}$ ratio of $\mathrm{Ca}^{2+}+\mathrm{Mg}^{2+}$ to $\mathrm{SO}_{4}^{2-}$ (Figure 6c) is much greater than 1, indicating that the $\mathrm{Ca}^{2+}$ and $\mathrm{Mg}^{2+}$ in the QT border areas water samples is closely related to $\mathrm{HCO}_{3}^{-}$. The ions (their types and concentrations) are mainly controlled by carbonate weathering; and the $\mathrm{Ca}^{2+}$ and $\mathrm{Mg}^{2+}$ may originate from the weathering of carbonate minerals (e.g., calcite and dolomite).

The $\mathrm{mEq}$ ratio of $\mathrm{Na}^{+}$to $\mathrm{HCO}_{3}^{-}$(Figure $6 \mathrm{f}$ ) in most of the water samples is less than 1 , while the mEq ratio of $\mathrm{Na}^{+}$to $\mathrm{SO}_{4}^{2-}$ (Figure $6 \mathrm{~g}$ ) in the western and northeastern border area water samples is approximately equal to 1, suggesting that the dissolution of sulfate minerals (e.g., mirabilite) may be among the sources of $\mathrm{Na}^{+}$in the water samples of western and northeastern areas (Zhe et al., 2017). Meanwhile, the mEq ratio of $\mathrm{Na}^{+}$to $\mathrm{SO}_{4}^{2-}$ (Figure $6 \mathrm{~g}$ ) in the southern area water samples is less than 1 . Therefore, the $\mathrm{Na}^{+}$in the southern border area water samples may originate from silicates (Zhe et al., 2017). Generally, the ratio of $\mathrm{Na}^{+}+\mathrm{K}^{+}$to $\mathrm{Cl}^{-}$is equal to 1 when the dissolution of evaporites plays a major role in hydrochemical compositions (Gibbs, 1970). Both the $\mathrm{mEq}$ ratios of $\mathrm{Na}^{+} / \mathrm{Cl}^{-}$(Figure 6h) and $\left(\mathrm{Na}^{+}+\mathrm{K}^{+}\right) / \mathrm{Cl}^{-}$(Figure 6i) are greater than 1, indicating that halite in evaporites (e.g., $\mathrm{NaCl}$ and $\mathrm{KCl}$ ) are the main source of $\mathrm{Cl}^{-}$in the water samples.

The ratio of $\left(\mathrm{Ca}^{2+}+\mathrm{Mg}^{2+}\right) /\left(\mathrm{Na}^{+}+\mathrm{K}^{+}\right)$in the water can be used as an indicator to distinguish the relative intensity of different rock weathering. Silicate weathering releases more $\mathrm{Na}^{+}+\mathrm{K}^{+}$ than $\mathrm{Ca}^{2+}+\mathrm{Mg}^{2+}$ (Sarin et al., 1989). Relatively high $\left(\mathrm{Ca}^{2+}+\mathrm{Mg}^{2+}\right) /\left(\mathrm{Na}^{+}+\mathrm{K}^{+}\right)$(Figure $\left.6 \mathrm{j}\right)$ and $\mathrm{SO}_{4}^{2-} / \mathrm{Na}^{+}$(Figure $6 \mathrm{~g}$ ) ratios indicate that the rocks are rich in $\mathrm{Ca}^{2+}, \mathrm{Mg}^{2+}$ and $\mathrm{SO}_{4}^{2-}$ (e.g., gypsum and dolomite) on the water sample hydrochemistry. The world's rivers average ratio of $\left(\mathrm{Ca}^{2+}+\mathrm{Mg}^{2+}\right) /\left(\mathrm{Na}^{+}+\mathrm{K}^{+}\right)$is 2.2 (Meybeck and Helmer 1989). Carbonate weathering may cause the high ratio of $\left(\mathrm{Ca}^{2+}+\mathrm{Mg}^{2+}\right) /\left(\mathrm{Na}^{+}+\mathrm{K}^{+}\right)$in a river/stream, such as the Lake Qinghai catchment in China which ranges from 5.5-20.3 (Hou et al., 2009), the carbonate bedrock section of Ganges-Brahmaputra River in India which ranges from 5.2-11.5 (Sarin and Krishnaswami, 1984), the Yangtze River in China which is 5.1 (Chen et al., 2002), the Indus River in India which is 6 (Ahmad et al., 1998) and the Mackenzie River in Canada which is 6.9 (Reeder et al., 1972). Conversely, the low ratio of $\left(\mathrm{Ca}^{2+}+\mathrm{Mg}^{2+}\right) /\left(\mathrm{Na}^{+}+\mathrm{K}^{+}\right)$in a river/ stream means it is probably controlled by the dissolution of evaporites, such as rivers around the Taklimakan Desert which are approximately 0.9 (Zhu and Yang, 2007), the Orinoco River in South America which is 1.5 (Nemeth et al., 1982) and the Buha-Heima River of the Lake Qinghai catchment which ranges from 1.36-6.81 (Hou et al., 2009). The QT border area water samples average ratio of $\left(\mathrm{Ca}^{2+}+\mathrm{Mg}^{2+}\right) /\left(\mathrm{Na}^{+}+\mathrm{K}^{+}\right)$decreases in the following order: northeastern $(23.8)>$ southern $(18.2)>$ western (9.8). This means that the process of carbonate weathering in the water has intensifies from the western to eastern QT.

\subsection{Anthropogenic input}

The hydrochemical characteristics of water can be affected by human activities (Meybeck and Helmer, 1989; Katz et al., 2001). Because of the rapid increase in industrial and agricultural activities, this impact has recently become significant in whole China (Chen et al., 
Table 4 Values of anthropogenic input geochemical variables in water compared with GB and WHO drinking water standards

\begin{tabular}{ccccccc}
\hline \multirow{2}{*}{ Parameter } & \multicolumn{3}{c}{ Border area of QT } & & GB & WHO \\
\cline { 2 - 4 } \cline { 5 - 6 } & Western & Southern & Northeastern & & $(\mathrm{MH} 2007)$ & (WHO 2008) \\
\hline $\mathrm{NO}_{2}^{-}(\mathrm{mg} / \mathrm{L})$ & n.a. & 0.02 & 0.08 & - & 3 \\
$\mathrm{NO}_{3}^{-}(\mathrm{mg} / \mathrm{L})$ & 3.41 & 1.71 & 4.38 & 44 & 50 \\
$\mathrm{SO}_{4}^{2-}(\mathrm{mg} / \mathrm{L})$ & 46.91 & 74.45 & 24.53 & 250 & 250 \\
$\mathrm{PO}_{4}^{3-}(\mathrm{mg} / \mathrm{L})$ & n.a. & n.a. & n.a. & - & - \\
\hline
\end{tabular}

n.a. (not applicable) means the concentration of parameter is lower than the LOD or is not detected.

2002). Generally, non-point source pollutants (i.e. fertilization) and surficial geological function (i.e. weathering) are the two important sources of $\mathrm{NO}_{3}^{-}$(Holloway et al., 1998). The presence of biogenic substances such as nitrogen, sulfur, and phosphorus compounds (e.g., $\mathrm{NO}_{2}^{-}, \mathrm{NO}_{3}^{-}, \mathrm{SO}_{4}^{2-}$, and $\mathrm{PO}_{4}^{3-}$ ) in natural water can reflect the impact of human activities on the chemical composition of water, to some extent (Roy et al., 1999).

The average nitrogen compounds in the order from the lowest to the highest are as follows (Table 4 and Figure 7): northeast $>$ west $>$ south. This order basically coincides with the socio-economic development in these areas. The average sulfur compounds have a general trend of south $>$ east $>$ west (Table 4). Phosphorus compounds in all the QT water samples were less than the limit of detection or were not detected (Table 4). One can see from Table 4 that all the biogenic substances in the water samples are very low and far lower than GB and WHO drinking water standards, indicating the QT is less affected by human activities.

\subsection{Spatial pattern of major ions}

Principal component analysis (PCA) of hydrochemical characteristics parameters derived three significant factors (Table 5). The percentages of variance indicate three components accounting for approximately $85.34 \%, 75.40 \%$, and $80.61 \%$ of the total variability water samples in the western, southern, and northeastern QT border areas, respectively. The scores of variables on the principal component vector are plotted in Figure 8.

PCA (Table 5, Figures $8 \mathrm{a}$ and $8 \mathrm{~b}$ ) of the western QT border area water samples shows strong relationships in the first component between Ec, TDS, TH, $\mathrm{Ca}^{2+}, \mathrm{Mg}^{2+}, \mathrm{K}^{+}, \mathrm{SO}_{4}^{2-}$, and $\mathrm{HCO}_{3}^{-}$, which indicate the carbonate weathering and evaporite dissolution (Gibbs, 1970; Chen et al., 2002). The relationships between $\mathrm{Na}^{+}, \mathrm{Cl}^{-}, \mathrm{NO}_{3}^{-}$, and $\mathrm{SiO}_{2}$ in the second component reflect the silicate weathering, evaporite dissolution, and some anthropogenic input (Gibbs, 1970; Cruz and Amaral, 2004). Because of the minimal amount of precipitation and human activities, silicate contributes more to the western QT (Yao et al., 1996; Chang et al., 2012). The $\mathrm{F}^{-}$shows the dominant nature in the third component (Figure 8b), which 

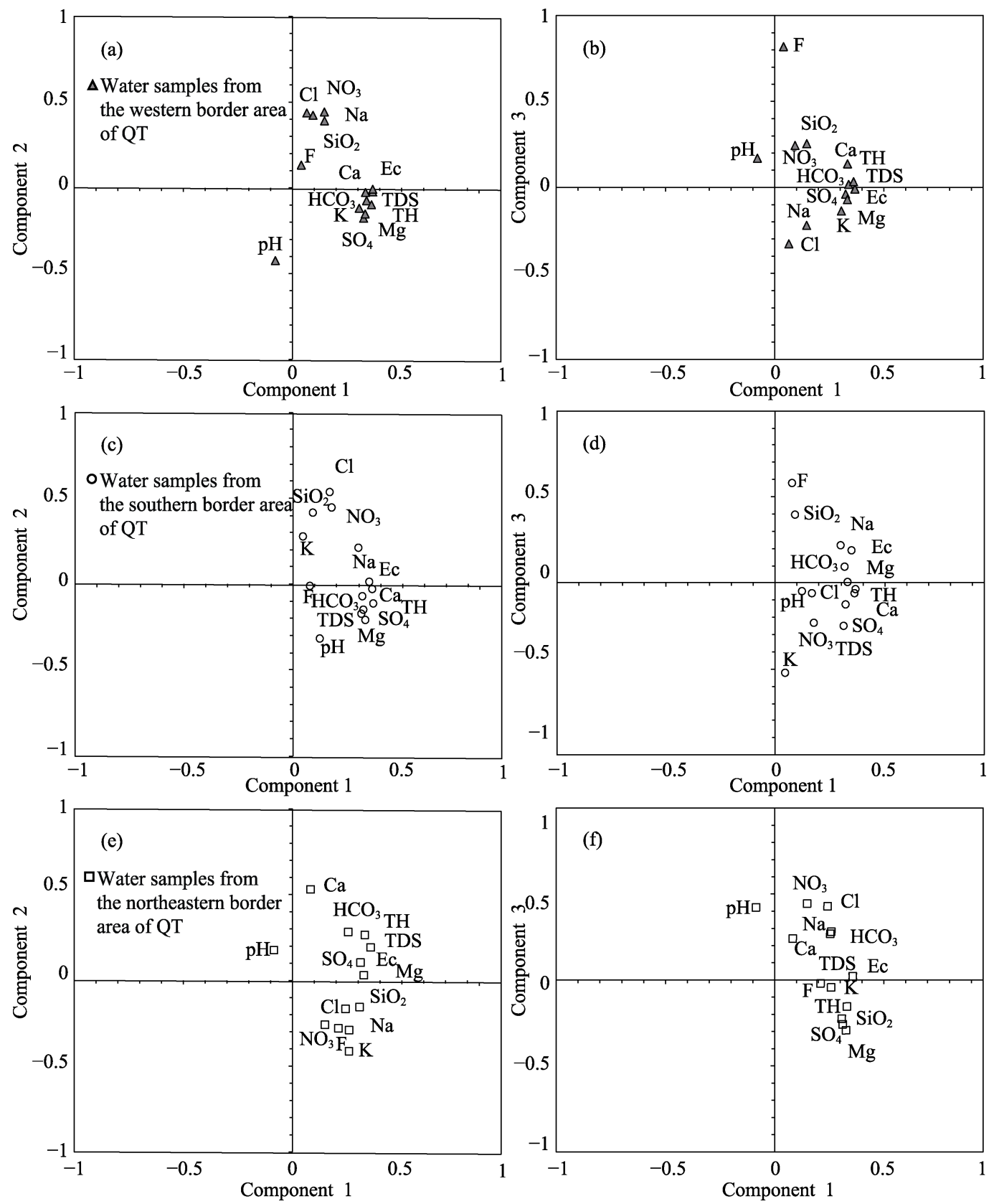

Figure 8 PCA results for variables: (a) component 1 and component 2 of water samples in the western border area, (b) component 1 and component 3 of water samples in the western border area; (c) component 1 and component 2 of water samples in the southern border area, and (d) component 1 and component 3 of water samples in the southern border area; (e) component 1 and component 2 of water samples in the northeastern border area, and (f) component 1 and component 3 of water samples in the northeastern border area of the Qinghai-Tibet Plateau

represents the geological and chemical characteristics of the rocks and soils (Meenakshi and Maheshwari, 2006).

Figures $8 \mathrm{c}$ and $8 \mathrm{~d}$ show strong relationships of the southern QT border area water samples among EC, TDS, TH, $\mathrm{Ca}^{2+}, \mathrm{Mg}^{2+}, \mathrm{Na}^{+}, \mathrm{SO}_{4}^{2-}$, and $\mathrm{HCO}_{3}^{-}$in the first component, indicating 
carbonate weathering and evaporite dissolutions; $\mathrm{K}^{+}, \mathrm{Cl}^{-}$and $\mathrm{NO}_{3}^{-}$in the second component, reflecting evaporite dissolutions and some anthropogenic input; and $\mathrm{SiO}_{2}$ and $\mathrm{F}^{-}$in the third component, showing silicate weathering and geological characteristic influence. Most of the parameters have some relationships in the first component, while only the $\mathrm{Ca}^{2+}$ correlation is greater in the second vector; $\mathrm{Cl}^{-}$and $\mathrm{NO}_{3}^{-}$are higher in the third vector. The correlations, predict common effects of multiple factors in the water samples of the northeastern border area of the QT (Figures 8e and 8f).

Table 5 Results of the PCA vectors, eigenvalues and \% of variance

\begin{tabular}{|c|c|c|c|c|c|c|}
\hline \multirow{2}{*}{ No. } & \multicolumn{2}{|c|}{ West } & \multicolumn{2}{|c|}{ South } & \multicolumn{2}{|c|}{ Northeast } \\
\hline & Eigenvalue & $\%$ of variance & Eigenvalue & $\%$ of variance & Eigenvalue & $\%$ of variance \\
\hline 1 & 7.3178 & 52.2703 & 6.9330 & 49.5215 & 6.9762 & 49.8304 \\
\hline 2 & 3.4631 & 24.7362 & 2.1551 & 15.3934 & 2.3914 & 17.0814 \\
\hline 3 & 1.1666 & 8.3326 & 1.4682 & 10.4873 & 1.9171 & 13.6934 \\
\hline 4 & 0.6698 & 4.7843 & 0.9467 & 6.7622 & 1.1243 & 8.0310 \\
\hline 5 & 0.4954 & 3.5387 & 0.7184 & 5.1313 & 0.7262 & 5.1872 \\
\hline 6 & 0.3340 & 2.3859 & 0.7059 & 5.0418 & 0.5176 & 3.6968 \\
\hline 7 & 0.2622 & 1.8729 & 0.4028 & 2.8774 & 0.1330 & 0.9501 \\
\hline 8 & 0.1449 & 1.0349 & 0.3045 & 2.1753 & 0.1023 & 0.7308 \\
\hline 9 & 0.1013 & 0.7236 & 0.2039 & 1.4561 & 0.0677 & 0.4835 \\
\hline 10 & 0.0368 & 0.2627 & 0.0923 & 0.6594 & 0.0241 & 0.1724 \\
\hline 11 & 0.0076 & 0.0542 & 0.0662 & 0.4728 & 0.0196 & 0.1397 \\
\hline 12 & 0.0005 & 0.0037 & 0.0019 & 0.0135 & 0.0005 & 0.0034 \\
\hline 13 & 0.0000 & 0.0000 & 0.0011 & 0.0079 & 0.0000 & 0.0000 \\
\hline 14 & 0.0000 & 0.0000 & 0.0000 & 0.0000 & 0.0000 & 0.0000 \\
\hline
\end{tabular}

Principal vectors are shown in bold.

\section{Conclusions}

In summary, through the collection, experimental measurement, and analysis of natural water samples from the three boundary areas of the QT where human activities exist, we found that water quality in the western, southern, and northeastern border areas of the QT was generally good, and most samples meet the drinking water standards. In addition, some indicators of individual water samples were even superior to the standards for drinking mineral water in China.

The QT water samples have the $\mathrm{pH}$ values ranging from 6.52 to 8.88 , with an average of 7.75 , being weakly alkaline. Furthermore, there were differences among the different boundary areas as follows: western areas (8.38), southern areas (7.57), and northeastern areas (7.66). The average TDS value in the QT water samples was $171 \mathrm{mg} / \mathrm{L}$ and the TDS were generally small. The QT water samples have the TH ranging from $3.69 \mathrm{mg} / \mathrm{L}$ (very soft) to $512 \mathrm{mg} / \mathrm{L}$ (very hard), with the average value of $168 \mathrm{mg} / \mathrm{L}$ (indicating a lower hardness).

The main cations were $\mathrm{Ca}^{2+}$ and $\mathrm{Mg}^{2+}$, while $\mathrm{HCO}_{3}^{-}$and $\mathrm{SO}_{4}^{2-}$ were the main anions. The main types of hydrochemistry in the three border areas were $\mathrm{Ca}^{2+}-\mathrm{Mg}^{2+}-\mathrm{HCO}_{3}^{-}-\mathrm{SO}_{4}^{2-}$ and 
$\mathrm{Ca}^{2+}-\mathrm{Mg}^{2+}-\mathrm{SO}_{4}^{2-}-\mathrm{HCO}_{3}^{-}$to the west; $\mathrm{Ca}^{2+}-\mathrm{Mg}^{2+}-\mathrm{SO}_{4}^{2-}-\mathrm{HCO}_{3}^{-}, \mathrm{Ca}^{2+}-\mathrm{Mg}^{2+}-\mathrm{HCO}_{3}-\mathrm{SO}_{4}^{2-}$, $\mathrm{Ca}^{2+}-\mathrm{HCO}_{3}-\mathrm{SO}_{4}^{2-}, \mathrm{Ca}^{2+}-\mathrm{HCO}_{3}^{-}$, and $\mathrm{Ca}^{2+}-\mathrm{Mg}^{2+}-\mathrm{HCO}_{3}^{-}$to the south; and $\mathrm{Ca}^{2+}-\mathrm{Mg}^{2+}-\mathrm{HCO}_{3}^{-}$ and $\mathrm{Ca}^{2+}-\mathrm{HCO}_{3}^{-}$to the northeast, respectively.

The genetic type of the QT border area water sample mainly was rock weathering, and the ions in the water were mainly controlled by the carbonate weathering and the evaporite dissolution; the weathering process of carbonate rocks was more intense. The main source of $\mathrm{Cl}^{-}$in water samples of the QT border areas was the halite of the evaporites. Dissolution of sulphate minerals in the water may be among the sources of $\mathrm{Na}^{+}$in the western and northeastern border areas, while $\mathrm{Na}^{+}$in the water samples in the southern border area may have originated from silicates.

The concentration of nitrogen compounds from water samples in each boundary area from high to low were in the northeast, west, and south; this was largely consistent with the local socio-economic development level. Meanwhile, the general trend in the average concentration of sulfur compounds from high to low was in the south, east, and west. The biological quality indicators of the natural water in the border areas was far superior to GB and WHO drinking water standards, indicating that these areas have been little affected by human activities.

The regional differences in the hydrochemistry of water samples from various boundary areas mainly are the result of the combined effects of geographical environment and geological conditions. In addition, human activities have had certain effects on the regional hydrochemistry.

\section{References}

Ahmad T, Khanna P P, Chakrapani G J et al., 1998. Geochemical characteristics of water and sediment of the Indus river, Trans-Himalaya, India: Constraints on weathering and erosion. Journal of Asian Earth Sciences, 16(2/3): 333-346.

Cao D, 2013. Yangtze River source area water environment and hydrochemistry background characteristic [D].

Beijing: Engineering China University of Geosciences (Beijing). (in Chinese)

Cao J, Zhao Y, Liu J et al., 2000. Fluoride concentrations of water sources in Tibet. Fluoride, 33(4): $205-209$.

Chang H, Xu W, Yuan J et al., 2012. Current situation of grassland resources and grazing capacity in Ali, Tibet. Pratacultural Science, 29(11): 1660-1664. (in Chinese)

Chen J, Wang F, Xia X et al., 2002. Major element chemistry of the Changjiang (Yangtze River). Chemical Geology, 187(3/4): 231-255.

Cruz J V L, Amaral C S, 2004. Major ion chemistry of groundwater from perched-water bodies of the Azores (Portugal) volcanic archipelago. Applied Geochemistry, 19(3): 445-459.

Dalai T K, Krishnaswami S, Sarin M M, 2002. Major ion chemistry in the headwaters of the Yamuna river system: Chemical weathering, its temperature dependence and $\mathrm{CO}_{2}$ consumption in the Himalaya. Geochimica et Cosmochimica Acta, 66(19): 3397-3416.

Deng W, 1988. Research on fundamental characteristic of hydrochemistry in the region of the Changjiang River headwater. Scientia Geographica Sinica, 8(4): 363-370. (in Chinese)

Gao T, Kang S, Zhang Q et al., 2008. Major ionic features and their sources in the Nam Co Basin over the Tibetan Plateau. Environmental Science, 29(11): 3009-3016. (in Chinese)

Gibbs R J, 1970. Mechanisms controlling world water chemistry. Science, 170(3962): 1088-1090.

Grange M L, Mathieu F, Begaux F et al., 2001. Kashin-Beck disease and drinking water in Central Tibet. International Orthopaedics, 25(3): 167-169.

Guo J, Kang S, Zhang Q et al., 2012. Temporal and spatial variations of major ions in Nam Co Lake water, Tibetan Plateau. Environmental Science, 33(7): 2295-2302. (in Chinese)

Guo Q, Wang Y, 2012. Hydrochemical anomaly of drinking waters in some endemic Kashin-Beck disease areas of 
Tibet, China. Environmental Earth Sciences, 65(3): 659-667.

Holloway J M, Dahlgren R A, Hansen B et al., 1998. Contribution of bedrock nitrogen to high nitrate concentrations in stream water. Nature, 395(395): 785-788.

Hou S, Xu H, An Z, 2009. Major ion chemistry of waters in Lake Qinghai catchment and the possible controls. Earth \& Environment, 37(1): 11-19. (in Chinese)

Jin Z, Yu J, Wang S et al., 2009. Constraints on water chemistry by chemical weathering in the Lake Qinghai catchment, northeastern Tibetan Plateau (China): Clues from $\mathrm{Sr}$ and its isotopic geochemistry. Hydrogeology Journal, 17(8): 2037-2048.

Ju J, Zhu L P, Wang J et al., 2010. Water and sediment chemistry of Lake Pumayum Co, South Tibet, China: Implications for interpreting sediment carbonate. Journal of Paleolimnology, 43(3): 463-474.

Katz B G, Böhlke J K, Hornsby H D, 2001. Timescales for nitrate contamination of spring waters, northern Florida, USA. Chemical Geology, 179(1-4): 167-186.

Li S, Wang M, Yang Q et al., 2012. Enrichment of arsenic in surface water, stream sediments and soils in Tibet. Journal of Geochemical Exploration, 135(6): 104-116.

Li S, Yang L, Wang W et al., 2006. Study on the relationship between selenium concentrations in drinking water and Kaschin-Beck Disease in Tibet. Chinese Journal of Endemiology, 25(4): 428-429. (in Chinese)

Li S, Zhang Q, 2008. Geochemistry of the upper Han River basin, China, 1: Spatial distribution of major ion compositions and their controlling factors. Applied Geochemistry, 23(12): 3535-3544.

Lu Y, Li Y, Mimapuchi et al., 2016. Evolution of structural geology and metallogenic unite, Xizang (Tibet) Autonomous Region. Geological Review, 62(b11): 219-220. (in Chinese)

Meenakshi, Maheshwari R C, 2006. Fluoride in drinking water and its removal. Journal of Hazardous Materials, 137(1): 456-463.

Meybeck M, 1987. Global chemical weathering of surficial rocks estimated from river dissolved loads. American Journal of Science, 287(5): 401-428.

Meybeck M, Helmer R, 1989. The quality of rivers: From pristine stage to global pollution. Palaeogeography Palaeoclimatology Palaeoecology, 75(4): 283-309.

Ministry of Environment Protection of the People's Republic of China (MEP), 2002. Methods for Chemical Analysis of Water and Waste Water. Beijing: China Environmental Science Press. (in Chinese)

Ministry of Health of the People's Republic of China (MH), 2007. Standards Examination Methods for Drinking Water GB/T 5750-2006. Beijing: China Standards Press. (in Chinese)

Ministry of Health of the People's Republic of China (MH), 2007. Standards for Drinking Water Quality GB 5749-2006. Beijing: China Standards Press. (in Chinese)

National Bureau of Statistics of People's Republic of China (NBS), 2017. China Statistical Yearbook 2017. Beijing: China Statistics Press. (in Chinese)

Nemeth A, Paolini J, Herrera R, 1982. Carbon transport in the Orinoco River: The preliminary results. Nairobi, Kenya, Scientific Committee on Problems of the Environment/United Nations Environment Programme Sonderband Heft.

Nie L, 2011. Analysis of microbial indicators of drinking water in rural areas of six counties in Tibet. Tibet Medical Journal, 32(1): 56-57. (in Chinese)

Piper A M, 1944. A graphic procedure in the geochemical interpretation of water-analyses. Eos, Transactions American Geophysical Union, 25(6): 914-928.

Reeder S W, Hitchon B, Levinson A A, 1972. Hydrogeochemistry of the surface waters of the Mackenzie River drainage basin, Canada (I): Factors controlling inorganic composition. Geochimica et Cosmochimica Acta, 36(8): 825-865.

Roy S, Gaillardet J, Allègre C J, 1999. Geochemistry of dissolved and suspended loads of the Seine River, France: Anthropogenic impact, carbonate and silicate weathering. Geochimica et Cosmochimica Acta, 63(9): 1277-1292.

Sarin M M, Krishnaswami S, 1984. Major ion chemistry of the Ganga-Brahmaputra river systems, India. Nature, 312(5994): 538-541.

Sarin M M, Krishnaswami S, Dilli K et al., 1989. Major ion chemistry of the Ganga-Brahmaputra river system: Weathering processes and fluxes to the Bay of Bengal. Geochimica et Cosmochimica Acta, 53(5): 997-1009.

Shen Z, Zhu W, Zhong Z, 1993. Hydrogeochemical Basis. Beijing: Geological Publishing House. (in Chinese) 
Sheng Y, Rui Y, Yu Y, 2012. Heavy metal pollution in water of rivers and lake in Tibet by ICP-MS. Asian Journal of Chemistry, 24(11): 5403-5404.

Sun H, Zheng D, Yao T et al., 2012. Protection and construction of the national ecological security shelter zone on Tibetan Plateau. Acta Geographica Sinica, 67(1): 3-12. (in Chinese)

Sun R, Zhang X, Wu Y, 2012. Major ion chemistry of water and its controlling factors in the Yamzhog Yumco Basin, South Tibet. Journal of Lake Sciences, 24(4): 600-608. (in Chinese)

Sun R, Zhang X, Zheng D, 2013. Spatial variation and its causes of water chemical property in Yamzhog Yumco Basin, South Tibet. Acta Geographica Sinica, 68(1): 36-44. (in Chinese)

Tan L, Li F, Li Z et al., 2016. Study on groundwater characteristics and development in permafrost region of Tuotuo River. Yellow River, 38(5): 62-67. (in Chinese)

Tian Y, Yu C, Luo K et al., 2015. Hydrochemical characteristics and element contents of natural waters in Tibet, China. Journal of Geographical Sciences, 25(6): 669-686.

Tian Y, Yu C, Zha X et al., 2016. Distribution and potential health risks of arsenic, selenium, and fluorine in natural waters in Tibet, China. Water, 8(12): 568.

United States Environmental Protection Agency (EPA), 1993. Determination of inorganic anions by ion chromatography. Cincinnati, Ohio 45268, Environmental Protection Agency Environmental Monitoring Systems Laboratory Office of Research and Decelopment.

Wang J, Ju J, Zhu L, 2013. Water chemistry variations of lake and inflowing rivers between pre- and post-monsoon season in Nam Co, Tibet. Scientia Geographica Sinica, 33(1): 90-96. (in Chinese)

Wang L, 2016. Study on hydrochemical characteristics and its influencing factors in Yarlung Tsangpo River Basin [D]. Beijing: University of Chinese Academy of Sciences. (in Chinese)

Wang M, Li S, Wang H et al., 2012. Distribution of arsenic in surface water in Tibet. Environmental Science, 33(10): 3411-3416. (in Chinese)

World Health Organization (WHO), 2008. Guidelines for drinking-water quality. Geneva, World Health Organization: 186.

Wu W, Yang J, Xu S et al., 2008. Geochemistry of the headwaters of the Yangtze River, Tongtian He and Jinshajiang: Silicate weathering and CO consumption. Applied Geochemistry, 23(12): 3712-3727.

Xiao J, Jin Z, Zhang F et al., 2012. Major ion geochemistry of shallow groundwater in the Qinghai Lake catchment, NE Qinghai-Tibet Plateau. Environmental Earth Sciences, 67(5): 1331-1344.

Yao T, Thompson L G, Qin D et al., 1996. Variations in temperature and precipitation in the past 2000 a on the Xizang (Tibet) Plateau-Guliya ice core record. Science in China (Series D), 39(4): 425-433.

Yao Z, Rui W, Liu Z et al., 2015. Spatial-temporal patterns of major ion chemistry and its controlling factors in the Manasarovar Basin, Tibet. Journal of Geographical Sciences, 25(6): 687-700.

Zhang M, Gustafsson J E, 1995. The Tibetan Water Environment: Water Chemistry of Some Surface Waters in Southern Tibet. Ambio, 24(6): 385-387.

Zhang X, He Y, Shen Z et al., 2015. Frontier of the ecological construction support the sustainable development in Tibet Autonomous Region. Bulletin of Chinese Academy of Sciences, (3): 306-312. (in Chinese)

Zhang X, Li X, Budu et al., 2013. Analysis on sanitary surveillance of drinking water quality in Nyingchi region of Tibet in 2011. Tibet Medical Journal, 34(1): 62-64. (in Chinese)

Zhang X, Sun R, Zhu L, 2012. Lake water in the Yamzhog Yumco basin in south Tibetan region: Quality and evaluation. Journal of Glaciology and Geocryology, 34(4): 950-958. (in Chinese)

Zhang Y, Li B, Zheng D, 2002. A discussion on the boundary and area of the Tibetan Plateau in China. Geographical Research, 21(1): 1-8. (in Chinese)

Zhao T, Chen Y, Yao W et al., 2017. The spatiotemporal distribution of two bacterial indexes in a small Tibetan Plateau watershed. Water, 9(11): 823 .

Zhe M, Zhang X, Wang B et al., 2017. Hydrochemical regime and its mechanism in Yamzhog Yumco Basin, South Tibet. Journal of Geographical Sciences, 27(9): 1111-1122.

Zheng D, Tan J, Wang W, 2007. Environmental Geosciences Introduction. Beijing: Higher Education Press.

Zhu B, Yang X, 2007. Chemical characteristics and origin of natural water in the Taklimakan Desert. Chinese Science Bulletin, 52(13): 1561-1566. (in Chinese)

Zhu L, Ju J, Yong W et al., 2010. Composition, spatial distribution, and environmental significance of water ions in Pumayum Co catchment, southern Tibet. Journal of Geographical Sciences, 20(1): 109-120. 